LETTER TO JMG

\title{
MMP-20 mutation in autosomal recessive pigmented hypomaturation amelogenesis imperfecta
}

\author{
J-W Kim, J P Simmer, T C Hart, P S Hart, M D Ramaswami, J D Bartlett, J C-C Hu
}

J Med Genet 2005;42:271-275. doi: 10.1136/jimg.2004.024505

D uring mammalian tooth formation, two proteinases are secreted by ameloblasts: enamelysin (MMP-20) and kallikrein-4 (KLK4). Enamelysin is the early protease. It is expressed by ameloblasts throughout the secretory stage and part of the maturation stage. ${ }^{1-3}$ KLK4 is the late protease; its expression by ameloblasts begins in the transition stage and continues throughout enamel maturation. ${ }^{45}$ Expression of these two proteases overlaps during the transition and early maturation stages, when the bulk of the organic matrix component is removed from the enamel layer. Because of its early pattern of expression, its ability to generate the same pattern of amelogenin cleavages in vitro as those observed in vivo, ${ }^{6}$ and the nature of the dental phenotype in enamelysin knockout mice, ${ }^{7}$ MMP-20 cleavages are thought to play important roles in crystal elongation, proper formation of the dentino-enamel junction (DEJ), and in the maintenance of enamel rod organisation. The extracellular protein KLK4 is believed to be the predominant degradative enzyme that clears enamel proteins from the matrix during the maturation stage. ${ }^{8-10}$ There are a number of recent reviews in the literature on the roles of proteolytic enzymes in dental enamel formation. ${ }^{11-14}$

Enamelysin is a matrix metalloproteinase (MMP). In humans, enamelysin is expressed from a gene on chromosome 1lq22.3-q23 having 10 exons (all coding). ${ }^{15}$ The enamelysin protein has 483 amino acids, including the signal peptide, and folds into propeptide, catalytic, linker, and hemopexin domains. ${ }^{16}$ The active protease migrates as a doublet at 46 and $41 \mathrm{kDa}$ on zymograms. ${ }^{17}{ }^{18}$ Its only posttranslational modification is a disulphide bridge connecting the first and last amino acids of the hemopexin domain. ${ }^{19}$

Inherited enamel malformations show a variety of phenotypes that are grouped according to the thickness and hardness of the enamel layer and are described as hypoplastic, hypocalcified, or hypomaturation types of amelogenesis imperfecta (AI). ${ }^{20}$ AI can have an autosomal dominant, autosomal recessive, or an $\mathrm{X}$ linked pattern of Mendelian inheritance. The enamelysin null mouse provides some indication of which type of AI would result from a mutation in the MMP20 gene. The MMP20 null mouse $(-/-)$ displays multiple enamel defects, including disorganised enamel rods, enamel hypoplasia (thin enamel), and a tendency for the enamel to delaminate from the underlying dentine. The enamel layer retains more residual protein than in the wild type mouse, and has reduced microhardness.

To gain a better understanding of the role of MMP-20 in normal and defective enamel formation, we developed and used a strategy for mutational analyses of the human MMP20 gene and have identified the first MMP20 gene mutation in a family with amelogenesis imperfecta. We describe the enamel phenotype and discuss the potential effects of the MMP20 mutation on enamelysin expression.

\section{MATERIALS AND METHODS Proband}

The proband first presented at 6 years of age at the Pediatric Dentistry Clinic at the University of Michigan (fig 1). The

\section{Key points}

- We identified a homozygous mutation in the gene encoding MMP-20 (enamelysin) in two affected members of a family with autosomal recessive pigmented hypomaturation amelogenesis imperfecta (AI) (MIM 204700). This is the first reported mutation in the MMP-20 gene that causes disease.

- The identified mutation was in the intron 6 splice acceptor $(\mathrm{AG} \rightarrow \mathrm{TG})$.

- The enamel of the subjects' teeth was pigmented, and its surface was mottled and rough. Radiographically, the enamel layer was usually more opaque than the underlying dentine, but not in all areas, and was never as radio-opaque as normal enamel.

- We present a standardised nomenclature for reporting MMP20 mutations that designates this mutation as g.30 561A $\rightarrow$ T, c.954-2A $\rightarrow$ T, or IVS6-2A $\rightarrow T$.

dental phenotype resembled the autosomal recessive pigmented hypomaturation type of amelogenesis imperfecta. ${ }^{21}$ The teeth appeared normal in size, with some crowding. The enamel layer was pigmented, showing an agar brown discoloration. The surface of the enamel was mottled and rough, but hard and brittle. Chunks of enamel had fractured away from several teeth, most notably on the lingual of the maxillary right canine (no. 6), and the buccals of the mandibular left canine (no. 22), and right first bicuspid (no. 28). Radiographically, the enamel layer was usually more opaque than the underlying dentine, but not in all areas, and was never as radiopaque as normal enamel. The proband had an anterior open bite. His teeth were generally not sensitive, except in response to extremes in temperature. Composites were placed, but required periodic repairs as the enamel at the restoration margins tended to chip off from the teeth. The father of the proband was reported to be affected; he is currently edentulous and wears maxillary and mandibular complete dentures.

\section{Identification of kindred and enrolment of human subjects}

The study protocol and patient consents were reviewed and approved by the institutional review board at the University of Michigan. The kindred was identified when the proband presented to the pediatric dental clinic at the university for the restoration of chipped teeth and correction of an anterior open bite. Family members received a complete dental and oral examination, including panographic radiographs. Oral histories were obtained from the grandmother and uncle by telephone interview.

\section{Polymerase chain reaction}

From participating family members, $10 \mathrm{ml}$ of peripheral whole blood was obtained. Genomic DNA was isolated using 

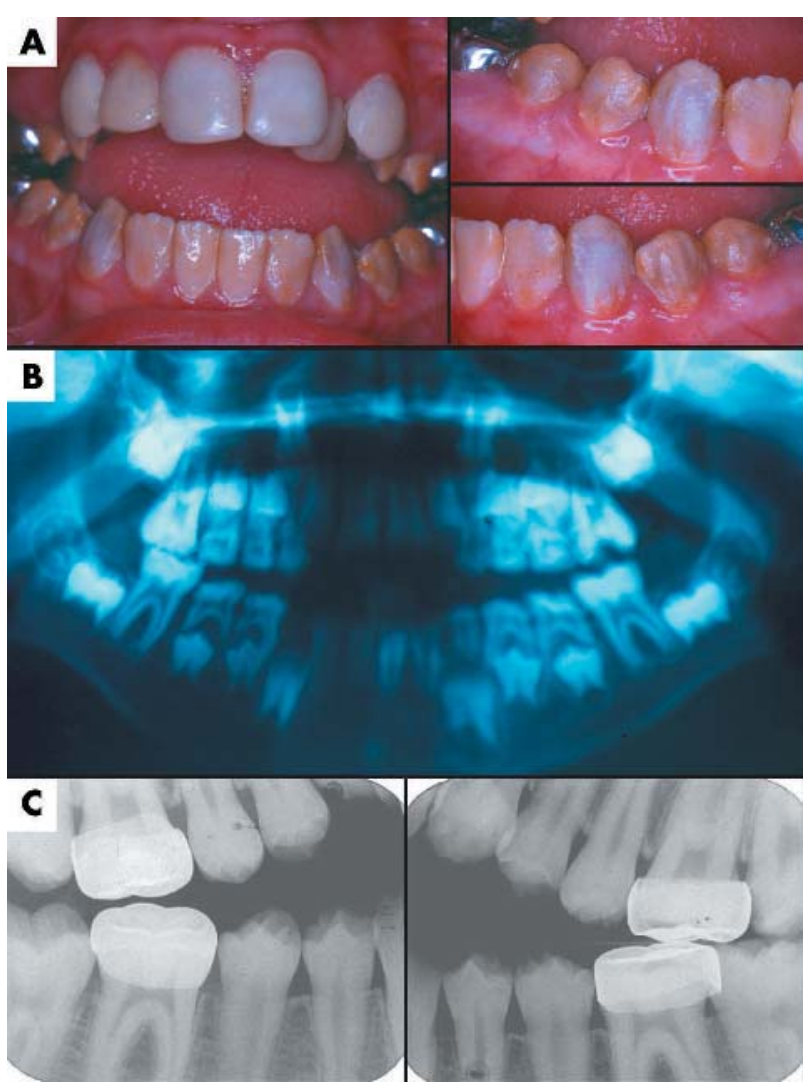

Figure 1 Phenotype of proband. (A) Photographs show frontal and lateral photographs of the proband at 12 years of age, showing composite veneer restorations on the maxillary anterior teeth. The unrestored mandibular anterior teeth show the mottled appearance and irregular staining. (B). Panorex radiograph of the same patient at 6 years of age. The anterior open bite is evident. (C). Bitewing radiographs of premolars and molars at 12 years of age show the lack of contrast between enamel and dentine, consistent with hypomaturation Al.

the QIAamp DNA blood maxi kit (Qiagen Inc., Valencia, CA). Oligonucleotide primers for polymerase chain reaction are shown in table 1 . The reactions had a 5 minute denaturation at $94^{\circ} \mathrm{C}$, followed by $40-50$ cycles of denaturation at $94^{\circ} \mathrm{C}$ for 30 seconds, primer annealing at the relevant temperature (table 1) for 30 seconds, and product extension at $72^{\circ} \mathrm{C}$ for 30 seconds, with a final extension at $72^{\circ} \mathrm{C}$ for 7 minutes. PCR amplification products were purified by the QIAquick PCR Purification kit and protocol (Qiagen Inc.).

MMP20 alleles were amplified using 200 random DNA samples taken from the general population and 50 samples from white subjects in the human variation panel of the Coriell Cell Repository (Camden, NJ, USA).

\section{Haplotype analysis}

Primers were designed to amplify five intronic regions of the MMP20 gene known to contain 17 single nucleotide polymorphisms (SNPs) (table 2). PCR was performed in a total volume of $25 \mu \mathrm{l}$ containing $1 \mu \mathrm{mol} / \mathrm{l}$ each forward and reverse primers, $1 \times$ PCR buffer, $1.5 \mathrm{mmol} / \mathrm{l} \mathrm{MgCl}{ }_{2}, 200 \mu \mathrm{mol} / \mathrm{l}$ dNTPs, 200 ng DNA, and 1 U of Taq DNA polymerase. Amplification conditions were an initial denaturation at $95^{\circ} \mathrm{C}$ for 5 minutes, followed by 35 cycles of denaturation at $95^{\circ} \mathrm{C}$ for 30 seconds, annealing at $58^{\circ} \mathrm{C}$ for 30 seconds, and extension at $68^{\circ} \mathrm{C}$ for 2 minutes, with a final extension at $68^{\circ} \mathrm{C}$ for 10 minutes. Following amplification, PCR products were gel purified and sequenced using the ABI Big Dye terminator kit and an ABI 3100 automated DNA sequencer. All products were sequenced
Table 1 Primers used to amplify MMP20

\begin{tabular}{|c|c|c|c|}
\hline Exon & Sequence $5^{\prime}-3^{\prime}$ & $\begin{array}{l}\text { Size } \\
\text { (bp) }\end{array}$ & $\begin{array}{l}\text { Annealing } \\
\text { temp ( } \mathrm{C} \text { ) }\end{array}$ \\
\hline 1 & $\begin{array}{l}\text { F: TACCCCATCATCAGGGAGAG } \\
\text { R: CCAGACACCAATCTAGGTGGA }\end{array}$ & 468 & 53 \\
\hline 2 & $\begin{array}{l}\text { F: CCCAAAACCAATCATCGTIA } \\
\text { R: GCCTGACGGATGGATGTAAA }\end{array}$ & 594 & 55 \\
\hline 3 & $\begin{array}{l}\text { F: TCCCTITCATTGTCTTGTTGTT } \\
\text { R: ATGGCTIGCCATGGTCTT }\end{array}$ & 482 & 53 \\
\hline 4 & $\begin{array}{l}\text { F: TTITCAATGGGCTGTIACTCA } \\
\text { R: CAACACAATITGGGGTGGAT }\end{array}$ & 485 & 53 \\
\hline 5 & $\begin{array}{l}\text { F: CACCAAAGCTAAGTGCCAGA } \\
\text { R: CAGCTCTTCACAAGAAGGCATAG }\end{array}$ & 468 & 55 \\
\hline 6 & $\begin{array}{l}\text { F: GAAGCTGAGGCTTGCAAAGT } \\
\text { R: ACCACCCTTCTGCTGCATAG }\end{array}$ & 490 & 55 \\
\hline 7 & $\begin{array}{l}\text { F: AGGCAAGGCAAGAGCAAAG } \\
\text { R: TAGGGTGGCATTCATACCC }\end{array}$ & 414 & 55 \\
\hline 8 & $\begin{array}{l}\text { F: ACTTTTGCCTCCAGGGAAGT } \\
\text { R: TCTGTAAATCGCACCCCAGT }\end{array}$ & 493 & 55 \\
\hline 9 & $\begin{array}{l}\text { F: TGGCACCACTACACTTCAGC } \\
\text { R: CAAACAAACAAACAAAAACTाTCC }\end{array}$ & 570 & 60 \\
\hline 10 & $\begin{array}{l}\text { F: GACAAGCTAACTGCCACCTGA } \\
\text { R: TGCAGAGTGCATGTGIGA }\end{array}$ & 484 & 55 \\
\hline
\end{tabular}

from both directions to minimise sequencing artefacts. Haplotypes were generated based upon allele transmission.

\section{RESULTS}

Mutational analyses were performed for the coding exons and intron-exon boundaries for five candidate genes (enamelin, ameloblastin, tuftelin, enamelysin, and kallikrein 4) believed to be critical for enamel development. The only gene found to differ from the wild type reference sequences was MMP20; the proband and his father were both homozygous for the same mutation (fig 2B). Clinical and pedigree analysis suggested a dominant pattern of inheritance of AI in this family; however, mutational analyses of the MMP20 gene was consistent with pseudodominance. Heterozygous carriers of the MMP20 mutation (I-2 and II-8) did not show clinical findings consistent with AI, while individuals homozygous for the MMP20 mutation (II-7 and III-11) demonstrated AI clinically and by history (fig 3). Similar findings have been reported for autosomal recessive AI caused by mutation of the ENAM gene. ${ }^{22}$ Current nomenclature recommendations

Table 2 Primers used for haplotype analysis of MMP2O

\begin{tabular}{|c|c|c|c|}
\hline $\begin{array}{l}\text { SNP } \\
\text { position* }\end{array}$ & Sequence $5^{\prime}-3^{\prime}$ & $\begin{array}{l}\text { Size } \\
\text { (bp) }\end{array}$ & rs \\
\hline $\begin{array}{l}-5816 \\
-5602\end{array}$ & $\begin{array}{l}\text { uF: TGACTGGGCAAGTGGAATGTG } \\
\text { uR: ACAGGGCAGGACTGACATGAG }\end{array}$ & 607 & $\begin{array}{l}948139 \\
948138\end{array}$ \\
\hline $\begin{array}{l}16991 \\
17081\end{array}$ & $\begin{array}{l}\text { i5F: CTCTGCACCCAGTCATGTAGC } \\
\text { i5R: GCCATCCGAAGGCAGTGACTT }\end{array}$ & 796 & $\begin{array}{l}1711422 \\
\text { Novel }\end{array}$ \\
\hline $\begin{array}{ll}17 & 494 \\
31 & 258 \\
31 & 275 \\
31 & 600 \\
32 & 101 \\
32 & 225 \\
32 & 231 \\
32 & 391 \\
32 & 444 \\
32 & 445\end{array}$ & $\begin{array}{l}\text { i7/8F: TCAGGAGGTGGACACATATAC } \\
\text { i7/8R: CAGTGATTGGATGACAGATGA } \\
\text { i7/8S: TCCCCACTACTGGATAACAAG }\end{array}$ & 1344 & $\begin{array}{l}1784421 \\
1711439 \\
1784439 \\
1784440 \\
1784441 \\
2292733 \\
1711440 \\
1711441 \\
7949109 \\
1784442\end{array}$ \\
\hline 35274 & $\begin{array}{l}\text { i8AF: GGACCCAGTTTTAGTGAATGA } \\
\text { i8AR: ATGCCCCGAGTCTGACTGTAC }\end{array}$ & 583 & 1711399 \\
\hline $\begin{array}{l}42789 \\
43055 \\
43201\end{array}$ & $\begin{array}{l}\text { i8BF: TTCCCGATCACTGTCCTACCT } \\
\text { i8BR: GTGGGCATTTGTTACATCATT }\end{array}$ & 562 & $\begin{array}{l}1784409 \\
1784410 \\
1784411\end{array}$ \\
\hline
\end{tabular}


for reporting sequence variations suggest using genomic and cDNA reference sequence. ${ }^{23-25}$ We used the MMP20 cDNA sequence for human MMP20 (NM_004771.2) and the human MMP20 gene sequence from human genome project chromosome 11 contig (NT 033899.6) as reference sequences. At the DNA level, the sequence variation that was present on both MMP20 alleles in the two affected members of our AI kindred is designated g.30 $561 \mathrm{~A} \rightarrow \mathrm{T}, \mathrm{c} .954-2 \mathrm{~A} \rightarrow \mathrm{T}$ or IVS6$2 \mathrm{~A} \rightarrow \mathrm{T}$. Sequence analysis did not reveal the g.30 561A $\rightarrow \mathrm{T}$ mutation in any of the 200 random controls (400 alleles) nor the 100 alleles for the white human variation panel.

As this family was not known to be consanguineous, the finding of homozygosity in two individuals raises the possibility of a mutational hotspot or of inheritance of a common allele identical by descent. To answer this question, we haplotyped individuals for 18 SNPs by direct sequencing (fig 3). The haplotype analysis demonstrates that II-5 and II-7 have inherited different parental haplotypes and are homozygous for all SNPs. Based upon previous haplotyping of white individuals, four predominant haplotypes were identified (data not shown). Three of these haplotypes (A, C, and $\mathrm{D}$ ) were found to segregate within this nuclear family.
I-2 has haplotype AD. Her unaffected son, II-5, is homozygous for the A haplotype, while her affected son, II-7, and grandson, III-11, are homozygous for the D haplotype. As expected, the mother of the proband, II-8, was found to be a carrier of the mutation. In addition, her haplotype (D) associated with the mutation is identical to that of her affected husband. Her other allele is haplotype C. Thus, the mutation has arisen on the D haplotype. These results would argue against a mutational hotspot and for inheritance of the mutant alleles identical by descent.

\section{DISCUSSION}

This is the first report of a mutation in the matrix metalloproteinase-20 (MMP20) gene. The gene is only known to be expressed in developing tooth enamel, and is also known as enamelysin (OMIM \#604629). The mutation destroys the splice acceptor sequence at the $3^{\prime}$ end of intron $6(\underline{A G} \rightarrow \underline{T G})$. Intron 6 is a large intron (11 $777 \mathrm{bp})$ that separates exons encoding the hemopexin domain (fig 2). The hemopexin domain is not critical for catalytic activity, but is highly conserved among the derived MMP-20 amino acid sequences from pig, ${ }^{2}$ mouse, ${ }^{26}$ cattle, ${ }^{27}$ and human. ${ }^{28}$ The

\section{A}

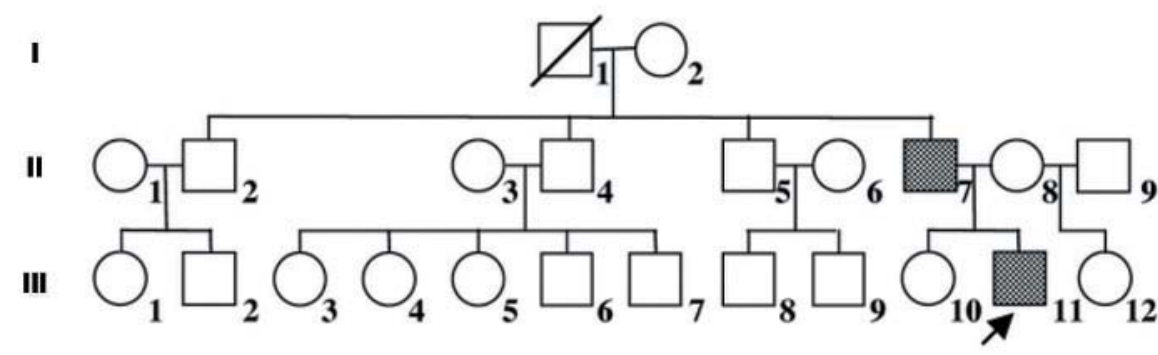

B

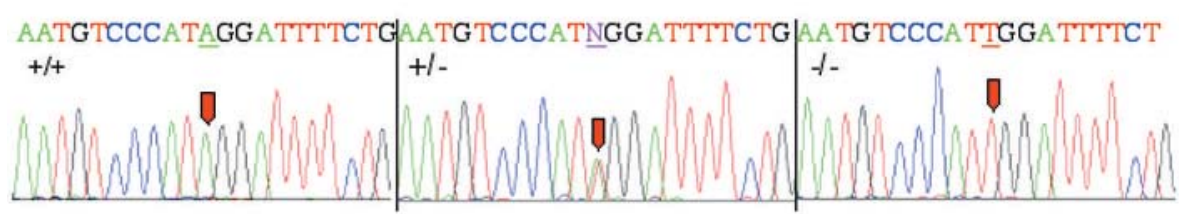

C

MMP-20 gene (48,216 bp; 11 q22.3-q23)

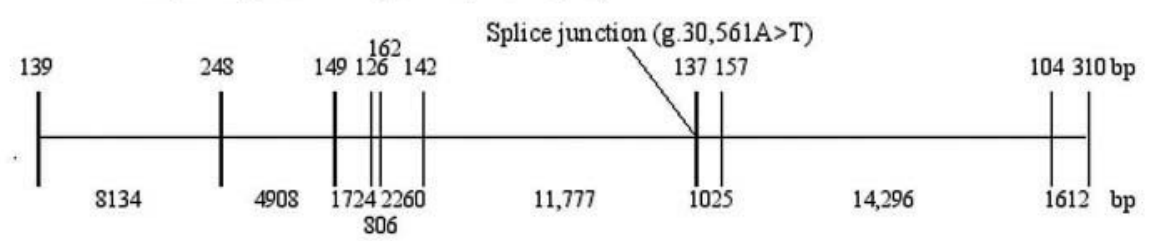

\begin{tabular}{|c|c|c|c|c|c|c|c|c|c|}
\hline $1-42$ & 43-125 & 126-174 & $175-216$ & $217-270$ & 271-318 & 319-363 & $364-416$ & 417-4: & $51-48$ \\
\hline 1 & 2 & 3 & 4 & 5 & 6 & 7 & 8 & 9 & 10 \\
\hline Sig & Propeptide & \multicolumn{3}{|c|}{ Catalytic Domain } & Lin & \multicolumn{4}{|c|}{ Hemopexin Domain } \\
\hline 1.22 & 23-107 & & 08.271 & & $272-295$ & & 296.483 & & \\
\hline
\end{tabular}

Figure 2 Pedigree and mutational analyses of the Al kindred. (A) Pedigree of the kindred with the $(\mathrm{g} .30561 \mathrm{~A} \rightarrow \mathrm{T}$; c. 954-2A $\rightarrow$ T or IVS6-2A $\rightarrow$ T) mutation. (B) DNA sequencing chromatograms are shown for wild-type $(+/+)$, heterozygous (+/ - ) and homozygous $(-/-)$ conditions. $A \rightarrow T$ transversion mutation site is indicated (arrows). (C) The structure of the human enamelysin gene marking the position of the mutation associated with $\mathrm{Al}$ is shown beneath the chromatograms. The exons are indicated by the 10 vertical lines; the introns are horizontal lines. Above each exon and below each intron are numbers indicating its length in base pairs. Below the gene structure, the 10 exons are aligned with a linear diagram of the MMP-20 structural domains. Above the exons are numbers indicating the range of amino acids encoded by each exon. Numbers beneath the protein structure indicate the range of amino acids in each structural domain. At the bottom of the figure is an alignment of the human MMP20 sequence with the two defective sequences that are most likely to result from the observed splice junction mutation. The wild type (wt) sequence is provided, beginning with the first amino acid (Cys ${ }^{296}$ ) of the hemopexin domain encoded in exon 6. A dash marks the end of the last amino acid ( $\mathrm{Arg}^{318}$ ) encoded by exon 6. Under the wild type sequence is the defective amino acid sequence (p.I319fs338X) that would be expected by joining exon 6 to exon 8 (Ex6-8). At the bottom is the defective amino acid sequence ( $p .1319 X)$ that would be expected if intron 6 is retained (+Int6). 
function of the enamelysin hemopexin domain is not known, but studies of other matrix metalloproteinases indicate that the enamelysin $\mathrm{C}$ terminal domain (CTD) might be essential for defining substrate specificity, binding to tissue inhibitors of metalloproteinases (TIMPs), and could be required for activation of proMMP-20 at the cell surface. ${ }^{29}$ Additionally, hemopexin domains may be functionally important in localising the protein substrate or binding to facilitate cleavage.

Because enamelysin gene expression is restricted to developing teeth, it was not possible to determine experimentally the effect of this mutation on MMP-20 mRNA transcripts, but it is clear that the IVS6-2A $\rightarrow \mathrm{T}$ mutation would preclude the specific removal of intron 6 by the splicing machinery. ${ }^{30}$ Two defective splicing outcomes seem to be most probable, both of which would introduce an upstream translation termination codon in the mRNA transcript, causing it to be degraded by the nonsense mediated decay (NMD) system. ${ }^{31-33}$ In the first splicing outcome, the retention of intron 6 in the mRNA would generate a large mRNA (over 13000 nucleotides in length) with translation terminating in the first complete codon of the retained intron (p.I319X). In the second splicing scenario, exon 7 would not be recognised as an exon by the splicing machinery and the intron 6-exon 7-intron 7 segment would be deleted as a single intron, as has been shown to occur in other splice acceptor site mutations. ${ }^{34}$ Skipping exon 7 would shift the reading frame after $\mathrm{R} 318$ and introduce 19 extraneous amino acids before terminating translation (p.I319fs338X). It seems likely that few of the defective MMP-20 mRNA transcripts would survive to be translated into protein during odontogenesis. If any proteins were synthesised, they would consist of native MMP-20 up to $\operatorname{Arg}^{318}$ and/or MMP-20 up to $\mathrm{Arg}^{318}$ plus a non-functional, if not toxic, extension of 19 amino acids. A summary of the likely effect of the g.30 561A $\rightarrow$ T mutation on the MMP-20 protein is shown in fig $2 \mathrm{C}$.

The principal functional deficits predicted from the g.30 561A $\rightarrow$ T mutation would be caused by $(a)$ the reduction of MMP-20 activity caused by degradation of its mRNA, and (b) through the loss of a functional hemopexin domain. The major consequence of diminished MMP-20 activity would be a failure to process and turn over enamel proteins during the secretory stage of amelogenesis and potentially a failure to activate KLK4 zymogen early in the maturation stage.

Proteolytic processing is believed to be essential for proper enamel crystal elongation, which determines the thickness of the enamel layer as a whole. Enamel hypoplasia (abnormally thin enamel), is a major feature of the defective enamel deposited by the enamelysin knockout mouse. ${ }^{7}$ In contrast to the enamelysin knockout, the teeth of our proband were heavily pigmented and not exceptionally thin (hypoplastic), suggesting a problem with the removal of enamel proteins, which normally occurs during the early maturation stage of enamel development. ${ }^{8}$ We speculate that in humans, the processing and turnover of enamel matrix proteins during the secretory stage is necessary for the ultimate clearance of the organic matrix during enamel maturation.

Autosomal recessive pigmented hypomaturation AI has recently been shown to have mutations in $K L K 4 .^{35} \mathrm{~A}$ comparison of the dental phenotypes of the KLK4 and MMP20 probands shows that they share many similar features. The enamel crowns are normal in size and shape, have a rougher, duller, less reflective surface than normal enamel, appear to be more brittle in that they show a tendency to fracture or chip, but do not appear to be particularly susceptible to dental caries. The radiodensity of the defective enamel is generally less than that of normal enamel, but can still be distinguished from the underlying

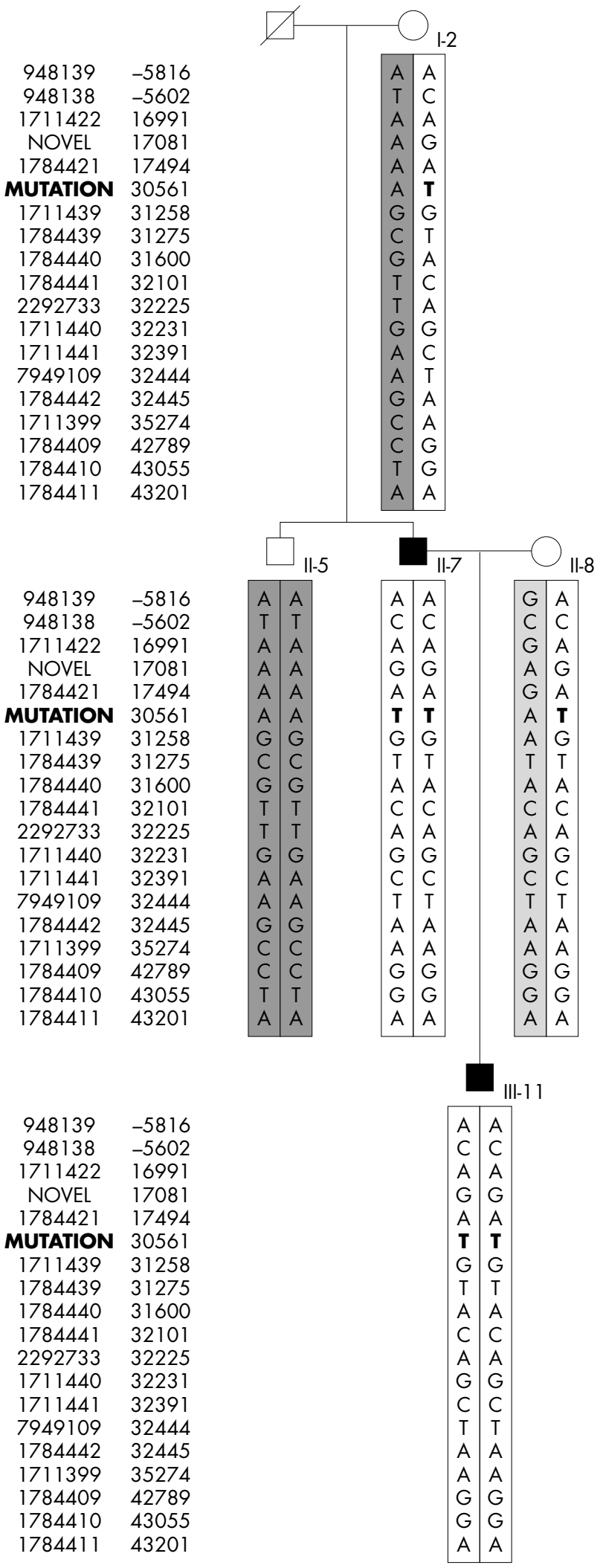

Figure 3 Haplotype analysis of the Al kindred. Five intronic regions of the MMP20 gene known to contain SNPs were PCR amplified and sequenced. Haplotypes were generated based upon allele transmission. The left column shows the reference SNP ( $r s$ ) number corresponding to each SNP while the right column shows the position in the MMP20 gene relative to the ATG start site, which is taken as +1 . The mutation (g.30 561T) is shown in bold, which is part of the D haplotype (unshaded boxes). The A haplotype is indicated by dark grey boxes. The C haplotype is indicated by a light grey box. 
dentine on radiographs. The coloration of the teeth is different, but extrinsic staining since tooth eruption could have contributed to the current appearance. The KLK4 teeth have a more homogenous dark yellow hue, while the MMP20 teeth have an irregular greyish brown discoloration and are a little more glossy. Overall, the dental phenotypes in the KLK4 and MMP20 probands are remarkably similar.

To date, mutations in four genes (AMELX, ENAM, KLK4, and $M M P 20$ ) have been found to cause amelogenesis imperfecta. Of these, three (ENAM, KLK4, and MMP20) can cause ARAI. ${ }^{36} 37$ While the recessive mutation in ENAM causes hypoplastic AI, ${ }^{22}$ mutations in the proteases cause hypomaturation ARAI. As mutational analyses clarify the genetic bases of the various AI phenotypes, a standardised nomenclature system can be developed. In turn, this system will enable clinicians to better predict which candidate gene might be defective, given the dental phenotype in their patients, and this knowledge will be useful when considering treatment alternatives, such as whether or not to attempt enamel bonding.

\section{ACKNOWLEDGEMENTS}

We thank the family for their participation, and the Pediatric Dental Clinic at the University of Michigan for their cooperation. This investigation was supported in part by the Foundation of the American Academy of Pediatric Dentistry, and USPHS Research Grants DE12769, DE15846, and DE11301 from the National Institute of Dental and Craniofacial Research, National Institutes of Health, Bethesda, MD 29892, USA.

\section{Authors' affiliations}

J-W Kim, Department of Pediatric Dentistry, College of Dentistry \& Dental Research Institute, Seoul National University, Seoul, Korea; and University of Michigan, School of Dentistry, Ann Arbor, MI, USA J P Simmer, Department of Biological and Material Sciences, University of Michigan School of Dentistry, Ann Arbor, MI, USA

T C Hart, National Institutes of Health, NIDCR

P S Hart, National Institutes of Health, NHGRI

M D Ramaswami, National Institutes of Health, NIDCR

J D Bartlett, Harvard-Forsyth Department of Cytokine Biology, The Forsyth Institute

J C-C Hu, Department of Pediatric Dentistry, University of Michigan School of Dentistry, Ann Arbor, MI, USA

Competing interests: there are no competing interests

Correspondence to: Dr J C-C Hu, Department of Orthodontics and Pediatric Dentistry, University of Michigan Dental Research Laboratory, 1210 Eisenhower Place, Ann Arbor, Ml 48108, USA; janhu@umich.edu

\section{REFERENCES}

1 Bègue-Kirn C, Krebsbach PH, Bartlett JD, Butler WT. Dentin sialoprotein, dentin phosphoprotein, enamelysin and ameloblastin: Tooth-specific molecules that are distinctively expressed during murine dental differentiations. Eur J Oral Sci 1998;106:963-70.

2 Bartlett JD, Simmer JP, Xue J, Margolis HC, Moreno EC. Molecular cloning and mRNA tissue distribution of a novel matrix metalloproteinase isolated from porcine enamel organ. Gene 1996;183:123-8.

3 Bartlett JD, Ryu OH, Xue J, Simmer JP, Margolis HC. Enamelysin mRNA displays a developmentally defined pattern of expression and encodes a protein which degrades amelogenin. Connect Tissue Res 1998;39:405-13.

4 Simmer JP, Sun X, Yamada Y, Zhang CH, Bartlett JD, Hu JC-C. Enamelysin and kallikrein-4 expression in the mouse incisor. In: Kobayashi I, Ozawa $\mathrm{H}_{\text {, }}$ eds. Biomineralization: formation, diversity, evolution and application. Proceedings of the 8th International Symposium on Biomineralization, Niigata, Jpn, Sept 25-28, 2001. Hadano, Japan: Tokai University Press, 2004;348-52).

5 Hu JC-C, Sun X, Liu S, Zhang CH, Bartlett JD, Simmer JP. Enamelysin and kallikrein-4 expression in developing mouse molars. Eur J Oral Sci 2002;110:307-15.

6 Ryu OH, Fincham AG, Hu CC, Zhang C, Qian Q, Bartlett JD, Simmer JP. Characterization of recombinant pig enamelysin activity and cleavage of recombinant pig and mouse amelogenins. J Dent Res 1999;78:743-50.

7 Caterina JJ, Skobe Z, Shi J, Ding Y, Simmer JP, Birkedal-Hansen H, Bartlett JD. Enamelysin (matrix metalloproteinase 20)-deficient mice display an amelogenesis imperfecta phenotype. J Biol Chem 2002;277:49598-604
8 Smith CE. Cellular and chemical events during enamel maturation. Crit Rev Oral Biol Med 1998;9:128-61

9 Ryu OH, Hu JC-C, Yamakoshi Y, Villimain JA, Cao X, Zhang CH, Bartlett JD, Simmer JP. KLK-4 activation, glycosylation, activity, and expression in prokaryotic and eukaryotic hosts. Eur J Oral Sci 2002;110:358-65.

10 Fukae M, Tanabe T, Nagano T, Ando H, Yamakoshi Y, Yamada M, Simmer JP, Oida S. Odontoblasts enhance the maturation of enamel crystals by secreting EMSP1 at the enamel-dentin junction. J Dent Res 2002:81:668-72.

11 Bartlett JD, Simmer JP. Proteinases in developing dental enamel. Crit Rev Oral Biol Med 1999;10:425-41.

12 Bartlett JD. Enamelysin. In: Barrett A, Rawlings N, Woessner J, eds. Handbook of proteolytic enzymes, vol 1. San Diego, CA: Academic Press, 2004:561-4.

13 Simmer JP, Hu JC-C. Expression, structure, and function of enamel proteinases. Connect Tissue Res 2002;43:441-9.

14 Simmer JP. Prostase. In: Barrett AJ, Rawlings ND, Woessner JF, eds. Handbook of proteolytic enzymes. Vol 2. San Diego, CA: Academic Press, 2004:1612-4

15 Caterina JJ, Shi J, Krakora S, Bartlett JD, Engler JA, Kozak CA, BirkedalHansen $\mathrm{H}$. Isolation, characterization, and chromosomal location of the mouse enamelysin gene. Genomics 1999:62:308-11.

16 Ryu OH, Hsiung D, Hu C-C, Sun X, Cao X, Bartlett JD, Simmer JP. The structure and function of enamelysin (MMP-20). In: Goldberg M, Boskey A, Robinson C, eds. Chemistry and biology of mineralized tissues: proceedings of the Sixth International Conference, 1998. Vittel, France: American Academy of Orthopaedic Surgeons, 2000:363-7.

17 Smith CE, Nanci A. Protein dynamics of amelogenesis. Anat Rec 1996;245:186-207.

18 Fukae M, Tanabe T, Uchida T, Lee SK, Ryu OH, Murakami C, Wakida K, Simmer JP, Yamada Y, Bartlett JD. Enamelysin (matrix metalloproteinase-20): localization in the developing tooth and effects of $\mathrm{pH}$ and calcium on amelogenin hydrolysis. J Dent Res 1998;77:1580-8.

19 Yamada Y, Yamakoshi Y, Gerlach RF, Hu JC-C, Liu S, Bartlett JD, Simmer JP. Purification and characterization of enamelysin from secretory stage pig enamel. Arch Comp Histol Tooth Form 2003;8:21-7.

20 Witkop Jr CJ, Sauk Jr JJ. Heritable defects of enamel. In: Stewart RE, Prescott GH, eds. Oral facial genetics. St. Lovis: CV Mosby Co, 1976:151-226.

21 Witkop Jr CJ. Amelogenesis imperfecta, dentinogenesis imperfecta and dentin dysplasia revisited: problems in classification. J Oral Pathol 1989;17:547-53.

22 Hart TC, Hart PS, Gorry MC, Michalec MD, Ryu OH, Uygur C, Ozdemir D, Firatli S, Aren G, Firatli E. Novel ENAM mutation responsible for autosomal recessive amelogenesis imperfecta and localised enamel defects. J Med Genet 2003;40:900-6.

23 Antonarakis SE. Recommendations for a nomenclature system for human gene mutations. Nomenclature Working Group. Hum Mutat 1998;1 1:1-3.

24 den Dunnen JT, Antonarakis SE. Mutation nomenclature extensions and suggestions to describe complex mutations: a discussion. Hum Mutat 2000;15:7-12

25 den Dunnen JT, Antonarakis SE. Nomenclature for the description of human sequence variations. Hum Genet 2001;109:121-4.

26 Caterina JJ, Shi J, Sun X, Qian Q, Yamada S, Liu Y, Karkora S, Bartlett JD, Yamada Y, Engler JA, Birkedal-Hansen H, Simmer JP. Cloning, characterization, and expression analysis of mouse enamelysin. J Dent Res 2000;79:1697-703.

27 Li W, Machule D, Gao C, DenBesten PK. Activation of recombinant bovine matrix metalloproteinase- 20 and its hydrolysis of two amelogenin oligopeptides. Eur J Oral Sci 1999;107:352-9.

28 Llano E, Pendás AM, Knäuper V, Sorsa T, Salo T, Salido E, Murphy G, Bartlett JD, Simmer JP, López-Otín C. Identification and structural and functional characterization of human enamelysin (MMP-20). Biochemistry 1997;36:15101-8.

29 Gomis-Ruth F. Hemopexin domains. In: Messerschmidt A, Bode W, Cygler M, eds. Handbook of metalloproteins, vol 3. Chichester: John Wiley \& Sons, Ltd, 2004:631-46.

30 Clark F, Thanaraj TA. Categorization and characterization of transcriptconfirmed constitutively and alternatively spliced introns and exons from human. Hum Mol Genet 2002;11:451-64.

31 Wagner E, Lykke-Andersen J. mRNA surveillance: the perfect persist. J Cell Sci 2002;115:3033-8.

32 Moore MJ. RNA events. No end to nonsense. Science 2002;298:370-1.

33 Maquat LE. Molecular biology. Skiing toward nonstop mRNA decay. Science 2002;295:2221-2

34 Bischoff AM, Luijendijk MW, Huygen PL, van Duijnhoven G, De Leenheer EM, Oudesluijs GG, Van Laer L, Cremers FP, Cremers CW, Kremer H. A novel mutation identified in the DFNA5 gene in a Dutch family: a clinical and genetic evaluation. Audiol Neurootol 2004;9:34-46

35 Hart PS, Hart TC, Michalec MD, Ryu OH, Simmons D, Hong S, Wright JT. Mutation in kallikrein 4 causes autosomal recessive hypomaturation amelogenesis imperfecta. J Med Genet 2004;41:545-9.

36 Kim J-W, Simmer JP, Hu YY, Lin BP-L, Boyd C, Wright JT, Yamada CJM, Rayes SK, Feigal RJ, Hu JC-C. Amelogenin p.MIT and p.W4S mutations underlying hypoplastic X-linked amelogenesis imperfecta. J Dent Res 2004:83:378-83.

37 Hu JC-C, Yamakoshi Y. Enamelin and autosomal-dominant amelogenesis imperfecta. Crit Rev Oral Biol Med 2003;14:387-98. 